\title{
ATTILA JÓZSEF’S ‘SZÜRKÜLET’ AND COVERT TRANSLATION
}

\author{
DANiEl ABOndolo \\ University College London, School of Slavonic and East European Studies
}

\begin{abstract}
Lyric poetry is 'interior meditative drama': it stages conflicting words instead of actual persons. ${ }^{\text {I }}$

Dramas are poems in the mode of action. ${ }^{2}$
\end{abstract}

IN this essay I have three main aims. ${ }^{3}$ First, I will elaborate a possible close reading of a poem, 'Szürkület' ("Twilight”") by Attila József (I905-37). Second, I hope to suggest reasons why

I Anna T. Szabó, citing Helen Vendler, on p. 2 of a review (entitled 'The Architecture of Poetry') of Helen Vendler's The Art of Shakespeare's Sonnets, Cambridge, MA, I997, in The Anachronist, I998, Department of English Studies, School of English and American Studies, ELTE < $\underline{\mathrm{http}}$ ://demo.insitemedia.hu/ theanachronist/docs/Anach oooo/szabo.doc > [accessed February 9 2006].

${ }^{2}$ Susanne Langer, quoted by Clifford Geertz, in Geertz, 'Blurred Genres: The Refiguration of Social Thought', reprinted as a chapter [pp. 19-35] in Local Knowledge: Further Essays in Interpretative Anthropology, 2nd edn, New York, 2000 (hereafter 'Blurred Genres'), p. 29. Langer's essay appeared originally in The American Scholar, 29, I980, 2.

${ }^{3}$ I thank my colleagues at UCL, and most particularly at the School of Slavonic and East European Studies, for their stimulating and helpful conversations. Comments by two anonymous referees and by my former student, Eileen Zwalf, all of whom read and commented on an earlier version of this essay, have also been extremely helpful. This is also the place to acknowledge and thank the invaluable online resources, the Nemzeti Szövegtár and the corpora of the Nagyszótár, both in progress, made available by the Linguistics Institute of the Hungarian Academy of Sciences.

4 To ensure clarity in a metalinguistically complex discussion, I adopt in my essay a commensurately complex set of typographic conventions. Double inverted commas are used to set off (I) paraphrase and (2) quotations within quotations (as opposed to [3] glosses and [4] ipsissima verba quotations, both set off by single inverted commas). Single inverted commas are also used to call attention to insidious metaphors, for example the reification of the spatial metaphor invoked by between in the phrase 'between' texts. As in this last example and in line with linguistic practice, not only foreign words but also all words and phrases cited qua words and phrases are given in italics.

5 Attila József wrote verse held to be of unrivalled excellence and stature in twentieth-century Hungarian literature. He was born April I I I905, of working-class parents. His father was absent from I908. József was placed with foster parents I9IO-I2 and I9I7-I8. His first suicide attempt (caustic soda) was at age nine. His mother died when he was fourteen (cancer of the uterus). József's second suicide attempt was in June I922 (medication overdose). He published, in December of the same year, his first volume of poetry: A szépség koldusa ("Beggar of beauty"), with a foreword by the poet Gyula Juhász. In I924-26 József attended the Universities of Szeged and Vienna, then the Sorbonne. József estranged the regnant literary arbiter Mihály Babits by means of mercilessly harsh lampooning verse and a pamphlet ('Egy költôre' "On a poet”, 'Az istenek 
the term 'close reading' in the narrowest sense, if it is to have any use, must refer to reading which takes the work and the artist's œuvre to be of a piece, and which attempts to perceive and grasp the work relative to any other texts which that reading finds illuminating. Close reading must operate in an awareness of the problematic nature of translation in the broadest sense, for the inevitability of repetition in its various guises means that intratextual and intertextual echoes abound for those with ears open to them. My third aim, flowing from the first two, is to examine the problematic nature of translation by sketching the manifold ways in which József's manner of writing in 'Szürkület' resembles Shakespeare's.

'Szürkület' is a poem fragment of about thirty lines (see Appendix). ${ }^{6}$ It is a monologue and a meditation on birth and death, child and parent, being and nothingness, the universe and the individual. It is therefore of a piece, thematically, with most of József's mature work. In the detail in which these themes are explored, and in certain formal respects, however, it is an atypical work: I am by no means suggesting that there is any pervasive Shakespearianness in József's writing.

To call attention to their broader senses I shall be using the words translate and translation in this essay to refer to a number of activities and achievements which go rather far beyond what they are usually taken to connote. Briefly: I shall be treating what is called translation as a kind, or more accurately, as kinds, of repetition. These kinds differ in degree, in other words, they form a continuum along an axis of degrees of repetition. The extremes of this axis are problematic: because of the chaotic flux, perfect repetition is impossible (Heraclitus, $\pi \dot{\alpha} v \tau \alpha$ @eĩ) but then so is, presumably, its opposite (nihil sub sole novum ${ }^{7}$ ), that is, partial repetition (and thereby: the possibility of parallelism) is unavoidable.

But translation, though it occupies a relatively median range on this axis, is itself problematic. This is exemplified adequately by Adam Makkai's remark on József's 'Születésnapomra' ("For My Birthday"): 'Although it is considered untranslatable, we present four versions of this poem. ${ }^{8}$ This is a remarkable sentence: the concessive 'although' seems to prepare the way for the boastful 'four', as if the higher the number of 'versions' provided, the greater the refutation of the idea that the work is untranslatable. In fact, the inverse comes nearer the mark. In the words of the hendecasyllabic proverb: Offerir molto è spezie di negare ("Offering [too] much is a kind of denial").

My extended use of the word translation is one way of tackling the problematic nature of the concept. Another way would be to eschew the use of the word translation entirely; but such

\section{Continued}

halnak, az ember él' "The gods die, Man lives", both I930). He joined the (illegal) Communist Party in 1930, and broke with it in I935. He alienated many in the Party with Reichian, mock-Marxian essays, for example: 'Egyéniség és valóság' "Individuality and Reality". He was in hospital for brief periods with a "nervous breakdown" (idegösszeomlás) in I928, I935, and I937. József committed suicide (under a goods train) December 3 I 937 .

${ }^{6}$ The text as we have it is in fact a composite, assembled by various editors over the years. The date of composition is uncertain: it may be I933, I934, I937, or a combination of these. József did not give it a title. Different versions have significant variations in several lines, or lines missing. Overall the variation is roughly I2 per cent, that is, tantamount to that between the first quarto and first folio versions of Shakespeare's King Lear. See Jay L. Halio (ed.), The Tragedy of King Lear, Cambridge, I992, pp. 58-59.

7 The supposedly 'equivalent' A.V. paraphrase, there is no new thing under the sun, lacks the concision and chiastic alliteration of the Vulgate. Here and elsewhere I cite in languages other than English not as verbal bravura, but rather to convey just such differences, which I take to be crucial.

${ }^{8}$ In Quest of the Miracle Stag: The Poetry of Hungary, An Anthology of Hungarian Poetry from the 13th Century to the Present in English Translation, vol. I, ed. by A. Makkai, Chicago, Budapest, I996, p. 662. 
a procedure would only avoid the problem. The difficulty of the concept behind the word translation may be highlighted by a consideration of the use of term itself, or of its 'equivalents' in other languages. Pertinent here is a sly and penetrating remark by the Transylvanian poet Oskar Pastior (born I927), with which I wholly concur: 'Übersetzung ist das falsche Wort für etwas, das es eigentlich nicht gibt' ("Translation is the wrong word for something that does not exist"). ${ }^{9}$ I take him here to be referring, in a nominalist vein, to the little-recognized fact that there is no clear dividing line between the various kinds of re-working of form and content that take place both within and between languages. The term translation is normally and rather narrowly used in English to refer, unproblematically, to (I) texts produced in one language, by conscious, motivated actors, in imitation of other texts in another language, or to (2) the process of this production itself. However, one remembers that the two texts thus related are not the same or indeed interchangeable. One also remembers that things closely akin to translation are also at play in such seemingly disparate events and actions as calques, paraphrase, interpretation, direct and indirect quotation, allusion, allegory, and: metaphor, a term of Greek origin whose Latin calque ${ }^{\mathrm{IO}}$ is translatio.

The design of my essay is as follows. After a compressed discussion of translation, text, and art, I catalogue examples of kinds of repetition, for example, loan translations, metaphor, paronomasia, that qualify as covert translation in that they translate parts of texts onto other parts of the same or other texts. The rest of the essay attempts to pinpoint what is Shakespearean about 'Szürkület'.

The mirror-image apophthegms cited at the start of this essay are meant to serve as an introduction to a circularity in the problematic nature of (kinds of) texts. I cite Langer in Geertz's context because I agree with the latter's argument that what we need, if we are to understand both 'the profoundest features of social processes' and the 'unpacking of performed meaning', is a synthesis of the dichotomies embodied in Kenneth Burke $v$. Victor Turner, ritual $v$. symbolic action theory, hedgehog $v$. fox, and experience $v$. expression. ${ }^{I I}$ But unlike Geertz, who opposes speech to 'text', then subdivides this latter into writingas-discourse $v$. action-as-discourse, ${ }^{\mathrm{I} 2} \mathrm{I}$ see the primary opposition as one of linguistic $v$. non-linguistic action. For me, all linguistic action (including metalinguistic and metametalinguistic ${ }^{13}$ action) is a subkind of symbolic, that is, social, action, and is opposed to, or at least fundamentally different from, non-linguistic action. In other words, actions ${ }^{14}$ include not only the creation of texts, whether spoken or written, but also the recognizing of texts as texts, or, more accurately, participation in the emergence of texts. Such participation takes place in the here and now, but the source materials from which the emergence occurs may

9 Cited in Paul Jandl, 'Fleischeslust und duale Reibe. Die Kulturtage Lana feiern Oskar Pastior' in Neue Zürcher Zeitung, $2002<$ http://engeler.de/ pressemappe_pastior.pdf> [accessed February 9 2006].

го The underlying metaphor of metaphor is transference: see Quintilian, Institutiones oratoriae 8.6.4; more on calques below.

II 'Blurred Genres', pp. 28-30.

I2 Ibid., pp. 30-3I.

I3 Or 'languaging': for a comparative-ethnographic integration of this Batesonian concept into a framework that encompasses translation, see Alton L. Becker's 'Attunement' in Becker, Beyond Translation: Essays toward a Modern Philology, Ann Arbor MI, I995, pp. 369-403.

${ }^{14}$ Here and elsewhere in this essay I use the term action, by metonymic and metaphoric extension, to cover events and activities as well. 
be buried deep in time: deep in the memory of the 'reader' and, in the case of written texts, deep in the history of culture. ${ }^{\text {IS }}$

Texts, then, are not here considered as things, ${ }^{16}$ but rather as emergent events occurring at the conjunction of Peircean signs, objects, and interpretants. Put another way, they are what we as 'readers' make of linguistic strings. This is why the phrase literal translation is a contradiction in terms, for texts literally cannot be translated. ${ }^{17}$ By the Heraclitean rule cited at the outset, repetition both 'within' a text and 'between' and 'among' texts may occur as replication of form or of content, but never of both, since the (linguistic) co-text and (extralinguistic) context will have altered. The precise nature of the 'content' will alter, and the precise nature of the form will also alter, as phonetic variation, whether induced by a metrical template or not. $^{18}$

Relatively clear examples of repetition of content rather than of form may be seen in the accumulation of synonyms 'within' a text, or the substitution of forms of 'equivalent' meaning in 'translated' texts. Thus when in 'Szürkület' József writes makacs 'stubborn'19 in line I5 and csökönyös 'obstinate' in line $17,{ }^{20}$ he draws attention to the putative (and problematic) synonymy of these words, giving rise thereby to the question: why not repeat the 'same' word? ${ }^{21}$ One is suspended between the poles, however vague, presupposed to separate and distinguish these two terms. This impression of suspension is enhanced, because of their arrangement in the text, by two formal factors: (I) each of these words occurs in a co-ordinative, paratactic syntagm (that is, via és 'and') with a further synonym-pair: kétszinü 'two-coloured; two-faced' and ravasz 'cunning'; (2) the order in which these synonyms occur is reversed, chiastically, providing a formal counterpoint to the semantic rhythm: makacs és kétszinü [...] ravasz és

Is What I describe here in terms of emergence is bound up with questions of artistic intention and style as well as the part/whole relationship between work and oeuvre, oeuvre and tradition, and the problematic nature of the notions 'text' and 'art' as a whole. My point of departure in this connexion has been guided chiefly by the pragmatics of Peirce and Dewey, the autopoiesis of Maturana and Varela, and much of the aesthetic theory of Danto. I have no difficulties with what Noël Carroll has termed 'backward causation', specifically the idea that 'artworks acquir[e] essential properties after they have been loosed upon the world and after their makers are long dead'. I think Carroll is correct, however, in asserting that 'intention does not explain style, rather style often helps to isolate the consolidation of artistic intention'. See Carrol, 'Danto, Style, and Intention', The Journal of Aesthetics and Art Criticism, 53, I995, 3, pp. 25 I-57.

${ }^{16}$ We usually do use the word text to refer, metonymically, to the audible percept or visible representation on the page, and I adhere to this usage here, as well.

${ }^{17}$ Danto gets this just right: 'as a thing, a text cannot be translated, just because things cannot be [translated]. (It is, incidentally, this innocuous logical fact regarding texts which has provoked, on the Continent, an astonishing flood of rhapsodic textolatry.)' Arthur C. Danto, The Transfiguration of the Commonplace: A Philosophy of Art, Cambridge MA, I98 I (hereafter Transfiguration), p. I88.

I8 Compare the four 'rhyming', but not all phonologically identical, uses of line-final megértünk in the quatrain by Sándor Weöres (I9I3-89), cited by János L. Nagy, Ismétlések és értelmezések Weöres Sándor verseiben ("Repetitions and interpretations in Sándor Weöres's poetry"), Budapest, I996, p. I7. Glossing megértünk in another language magnifies the vernier calibration of the Hungarian: 'we have reached; we have ripened; we understand; we are worth.'

I9 The reader is requested to bear in mind that all glosses are for identification purposes only, and imply no one-to-one correspondence from one language to another.

${ }^{20}$ Line numbers follow those of Béla Stoll in his edition József Attila összes versei, Budapest, I984 (hereafter, Stoll, $J A O ̈ V)$.

${ }^{21}$ Although elegant variation (in Henry W. Fowler's sense) occurs widely in Hungarian academic prose, apart from ironic use it is absent, by definition, from the language of poets. 
csökönyös 'stubborn and two-faced [...] cunning and obstinate'. We shall return to these and other synonyms in the Shakespearean section below.

For brevity's sake I here merely catalogue the kinds of repetition which can interact with translation, concentrating on those that occur with most frequency in József's 'Szürkület'. We shall also return to some of these in the last, Shakespearean, section. Calques. At the lexical level, calques, or 'loan translations' are for the most part the given, ready-made wherewithal with which language-users work. What is generally under-appreciated is their quasi-ubiquity and their deep-rootedness. ${ }^{22}$ Among calques of various kinds, in our text one may single out szürkület 'dusk' (derived from szürke 'grey', szürkül 'become/glow/appear grey'), a calque to German Grauen; kecs 'charm, grace', earlier 'Liebreiz, Anmut', a back-formation initiated by Gábor Dayka (I769-96) from the verb kecseget 'to lure, attract (animals)', on a rococo analogy deriving from French attraits : attraire (trahere, to pull) :: Reiz : reizen (causative to reißen); ${ }^{23}$ and egyén 'individual; person', consciously constructed c. I 8 I 5 from egy 'one' and én 'I; ego'. Although the Hungarian word is constituted of parts which in no way reflect the Latin roots and affixes seen in the sources of English individual or person, in the light of József's compound tárgy-egyén 'object-individual', we may see a close tie to the ein, 'one', of the literary German Einzelwesen 'individual'.

These three words occur in the first four lines of 'Szürkület', and by selecting them József focuses our attention on the ambiguity of twilight (greyness, not black-or-white), the threat that the dismantling of dark poses to the self (sublimation of separate identities into some vague universe), and the delicacy, even feminine charm, of the setting in which we are invited to watch this dismantling take place. Kecs was an extremely rare word by the twentieth century; here it lends a note of preciousness as well as vulnerability. ${ }^{24}$ The blended, double quality of greyness comports with the "two-coloured" (kétszinú) sub-theme of the text. Metaphor is a kind of repetition in that, at the simplest level, it entails the assertion A $=\mathrm{B} .^{25}$ Metaphor is also a kind of translation, in that it always involves interpretation, viz. understanding one conceptual domain in terms of another. Metaphor may also be seen as operating at the lexical level, in the sense that it is either deeply embedded, as in the case of conventional metaphors such as 'death is darkness/night', 'a lifetime is a day/year', or is built afresh on the

${ }^{22}$ For Hungarian, the most compendious treatment is by Eva Martins, Studien zur Frage der linguistischen Interferenz. Lehnprägungen in der Sprache von Franz von Kazinczy (1759-1831) (Acta Universitatis Stockholmiensis, Studia Hungarica Stockholmiensia, no. 2), Stockholm, I970 (hereafter Martins, Interferenz). An attempt at exhaustiveness of subkinds of loan translation, plotting form, meaning, and their relation in a threedimensional matrix, is made by Craig Hilts in his 'From Taxonomy To Typology: The Features of Lexical Contact Phenomena in Atepec Zapotec-Spanish Linguistic Contact', a paper in the Ohio State University Linguistics Department's Working Papers in Linguistics < http://ling.ohio-state.edu/publications/osu_wpl/ osuwpl $57>$ [accessed February 9 2006].

${ }_{23}$ Compare Martins, Interferenz, p. I46, and Lutz Mackensen, Deutsche Etymologie: Ein Leitfaden durch die Geschichte des deutschen Wortschatzes, Birsfelden-Basle, I977, pp. I30, I44.

${ }^{24}$ There is also oxymoron in this sense and note, since it is not the branches themselves that hold up the air, but rather their "structures" or "mechanisms" (szerkezetei, a paronym to szürkület).

${ }_{25}$ That is, 'A is B' and its syntactic permutations (and 'equivalents' in other languages). Empson's Chapter I9, in which he discusses metaphor and related matters in connexion with this simple-seeming formula, is still the most helpful in this connexion. Much fine detail in his argumentation, however, does not apply to Hungarian, mainly because Hungarian encodes definiteness differently from English. William Empson, The Structure of Complex Words [I95I], Ann Arbor, MI, I967 (hereafter, Complex Words). 
basis of such conventional metaphors. ${ }^{26}$ In 'Szürkület', the main metaphors analogize death with day's and year's end, twilight (greyness) with indeterminacy, loss of identity, and duplicity, and birth with physical deformity, muteness, and nothingness. In this text, one is not born into this world from the néant: one gives birth to néant. In an extended simile, the persona's instinct is likened to a dog scolded by its master, but the image is blurred because, though the dog howls, it does not "speak". The personification of the instinct-dog is complete by line Io: olyan most "o" "such is he, now". The centre of gravity of the third-person pronoun 0 is in human beings, and its use to refer to referents 'lower' on the animacy hierarchy always entails personification. ${ }^{27}$ There is repetition, then, on at least two levels: the usual $\mathrm{A}=\mathrm{B}$, the instinct $=$ dog of metaphor, plus the parallelism of "would fain give answer" (that is, does not answer) and "does not speak", that is, dog = person. The image is further obscured by the indeterminacy of the explicitly human actors: Who is the dog's master? Who is the "stranger" at whom the dog can only howl? One thing seems certain: the impotence of the persona's instinct means that all that is left is error: 'Csak egy bizonyos itt — az, ami tévedés' (line I I), which we may paraphrase as "Only one thing is certain here: that which is error". This predicament is a logical consequence of the failure of instinct: 'Lo naturale è sempre senza errore'. ${ }^{28}$ Lists (enumeratio) are a third kind of repetition in 'Szürkület'. They take the form of a detailed enumeration, taking up roughly a quarter of the text, of examples of how others behave towards the persona (lines I 8-24). Enumeration is yet another kind of translation, in that as partial repetition it amplifies, builds on, and explicates what has already been said. Four kinds of other person are mentioned in sections whose length swells, then shrinks. First, there is one who winks at the persona and addresses him with the somewhat contemptuous szép fiún (line I 8), then another who explicitly insults him ('hideous carrion') and accuses him of being lazy (lines I9-20), and a third who thrusts a coin into his hand and wishes him well, even expressing sympathy ("I understand you; I, too, have suffered enough"). The last one, however, robs the persona even of his rubbish..$^{30}$ Enumeration here, while intratextual repetition of a kind, is also repeated outside this poem across József's entire œuvre: like Rabelais, Swift, and Shakespeare, József loved lists. ${ }^{3 \mathrm{I}}$ Paronyms are yet another kind of repetition, a phonolexical repetition. ${ }^{32}$ Towards the beginning of 'Szürkület' paronyms form clusters that function as enigmatic signifiers, ${ }^{33}$ for example, szürkület—szerkezet "dusk—mechanism" (lines I-2),

${ }^{26}$ See George Lakoff and Mark Turner, More than Cool Reason: A Field Guide to Poetic Metaphor, Chicago, I989, esp. pp. $27 f f ., 67$.

${ }^{27}$ The orthoëpist M. Kovalovszky even uses $o^{\prime \prime}$ to refer, at one point, to the Hungarian co-verb meg, thereby attributing to it not only agency but even malevolence. L. Grétsy and M. Kovalovszky (eds), Nyelvmüvelö kézikönyv, Budapest, I985, vol. 2, p. II2.

${ }^{28}$ Dante, Purgatorio I 7.94, paraphrased as “Az ösztönből tévedés nem eredhet” ("From instinct error cannot arise”), by Mihály Babits in Dante összes müvei [1920], Budapest, I962, p. 753.

29 Compare goodman boy in King Lear (II.2.39).

${ }^{30}$ Compare Iago's 'Who steals my purse steals trash' (Othello, III.3.I 57).

${ }^{31}$ Perhaps the most notorious example is his poem of I926, 'Ülni, állni, ölni, halni' ("To sit, to stand, to kill, to die"), which in its first twenty-nine lines lists twenty-eight alternative (or cumulative?) acts as infinitives.

${ }^{32}$ I use this term here to refer to words whose names have similar shapes, whether their senses are similar or not. For detailed discussion, see Daniel Abondolo, A Poetics Handbook: Verbal Art in the European Tradition, Richmond, 200I, esp. pp. I38-47.

${ }_{33}$ Compare, from a Freudian perspective, Jonathan Lear, Happiness, Death, and the Remainder of Life, Cambridge MA, 2000, p. 2 I. 
tar-tartják — tárgy "bare - they sustain it-object" (lines 2-4), or the looser but more complex rideg-idegen "bleak/unfriendly_foreign(er)/strange" interlocking with borong-rávonit "broods/is gloomy-howls at him" (lines 8-9). There is also the possibility of a pun (paronomasia) in József's use of the word(s) púp: alongside the standard lexical item, glossed 'hump on back', there is also a dialect word, a Slavonic loan, meaning 'navel; umbilicus'. ${ }^{34}$ Openness to this polysemy allows one to see the even deeper connexions between the persona and the insane mother of his simile in lines $26-28 .{ }^{35}$ Parataxis is the dominant structure of 'Szürkület', both in hendiadys ${ }^{36}$ and in other, quasi-synonymic pairs (szép fiu : randa dög "nice boy : vile cur", ideránt : odahúz "yanks me this way : pulls me that way", hordok : viselem "I carry : I bear"). Hypotaxis occurs only in the two similes (instinct $=\mathrm{dog}$, persona $=$ mother) and in the transitional lines, II-I3, roughly halfway through the poem (hypotaxis underscored):

Csak egy bizonyos itt - Az, ami tévedés.

Még jó, hogy vannak jambusok és van mibe beléfogóznom. ${ }^{37}$

The rest is co-ordination (parataxis), asyndetic in lines $\mathrm{I}-4$, then linked by és 'and' or de 'but' in lines 5, 7-9, and I2. Although a monologue, the text is non-monologic: the persona quotes and paraphrases the speech and thoughts of others and interrupts himself to ask three rhetorical questions: "Who knows?", "What could I do without it?" and "How should I know?" (lines 6, IO, I7).

Taking our lead, with Arthur C. Danto, from Charles Sanders Peirce ('the man is the sum total of his language, because man is a sign ${ }^{\prime 3}{ }^{8}$ ), we may define style as the way of representing whatever a person represents. If, as I assume here, the work and the (wo)man are of a piece, any one work may, in principle, be used as a prism or lens to view the (wo)man and the work as a whole. ${ }^{39}$

We are now in a position to survey how the text referred to as 'Szürkület' by József's editors is stylistically similar to texts by Shakespeare, chiefly the later plays, but also the sonnets. The order of presentation moves from the more general to the more specific, as follows: (I) general stylistic features; (2) thematic and rhetorical similarities; (3) stylistic and rhetorical specifics; (4) textual and lexical specifics.

${ }^{34}$ Loránd Benkő (ed.), A magyar nyelv történeti-etimológiai szótára (hereafter: TESz), Budapest, I976, vol. 3, p. 3 II.

35 Zsuzsa Beney has written in some detail on the inverted mother/son imagery at work here and in related texts by József in an essay entitled 'József Attila inverz anyaképei', in Forrás, December $2003<$ http:// rkk.hu/forras/O3 I2/beney.html> [accessed February I2 2006]. Beney characterizes the "diction" (dikciója) of 'Szürkület' as "foreign" (idegen) and reminiscent of that of Milán Füst.

${ }^{36}$ In keeping with the conceptual vein pursued here, we may define hendiadys as hypotaxis couched collocated - as parataxis: again, translation.

${ }^{37}$ I believe Péter Szilágyi was the first to notice that line $\mathrm{I} 2$ is the only line in the poem entirely lacking in iambs, József Attila idómértékes verselése, Budapest, I971, p. 46. See my Appendix, pp. I57-58.

${ }^{8}$ Transfiguration, p. 205.

39 In a similar way, but on a different scale, any one grammatical or phonological aspect of a language may serve as the prism or lens through which the rest of the grammar and phonology is viewed. A sterling example of this is Juha Janhunen's Glottal Stop in Nenets, Helsinki, I986. 
Particularly in his later plays and in most of the sonnets, complexity of thought and opacity of expression are central to Shakespeare's style..$^{\circ} \mathrm{I}$ will try to show here how and to what extent József's 'Szürkület' is his most Shakespearean poem.

Complexity of thought, in Shakespeare and elsewhere, arises from the use of what Empson impishly called 'complex words'; a clearer designation, perhaps, would be 'word complexes'. Whatever we call them, these arise because, properly placed, words interanimate one another, sparking, in texts of high density, meaning potentials that are so numerous and intertwined that we cannot count or disentangle them conclusively. In this sense, there are no 'key words' in highly cohesive, dense texts: all the words are key. ${ }^{4 \mathrm{I}}$ Opacity of expression, normally seen as a fault, is also characteristic of Shakespeare in the sense that there is often, again especially in the later work, no clear indication of what is meant by a word, or combination of words, or a sentence, speech, or scene. And hence the idea that Hamlet, as a whole, is an enigma (see Vygotsky, again), or, on a smaller scale, that we do not know why Hamlet delays his revenge, if, indeed, he delays it at all. ${ }^{42}$

What is particularly Shakespearean about Shakespeare's language is the simultaneity of this complex thought and opaque expression. His thought proceeds dialogically, and questions and answers are strung into a linguistic sequence whose syntax does not necessarily make their disposition or interdependence clear. I am not thinking here of depth, but Anthony Savile's quotation of Wilhelm Meister is apt in this connexion: 'It seems as if he [Shakespeare] dissolves all puzzles for us, yet without it being possible for us to say that here or there we have the key.' ${ }^{33}$

In 'Szürkület' we have semiotic complexity and linguistic opacity similarly conjoined. Though just thirty lines long, it manages to include a landscape with adumbrations of cosmic annihilation; an exploration of the persona's impuissant and mute instinct ${ }^{44}$ (seen through a simile comparing it to a dog); assertions concerning the ubiquity of error and the reassurance of metre; speculation on why the persona cannot be a child, and whether he is more stubborn and sly than anyone else; a detailed description of others' abuse of the persona, and the disclosure of the persona's secret weapon: a hump on his back that, for some reason, no one notices, and that he carries around "the way a deranged mother carries her foetus". And this is no ordinary foetus, since she (and not the persona?) thinks that through this foetus she will give birth either to "muteness" (némaságot) or to "ancestral, pure void" (ósi, tiszta ürt). One notices the recurrence of muteness and void after just a few dozen lines: it was the persona's instinct

$4^{0}$ The opacity is not merely due to the texts' age. Compare Frank Kermode, Shakespeare's Language, London, 2000, esp. p. 4: 'the language can admittedly be difficult, even baffling. This is obviously so for audiences coming in four hundred years after the event, but it must often have been true also of the original audiences, less because the language itself was unfamiliar [...] than because of the strange and original uses an individual writer might put it to.'

${ }^{4}$ I By key I mean in the manner of Empson on dog in Timon of Athens (Complex Words, Chapter 8), or in the manner of Vygotsky, who claimed that the word machine, in Hamlet's letter to Ophelia, held the very essence (самая суть) of that tragedy. Lev Vygotsky, Psikhologija isskustva, Chapter $8<$ http://lib.aldebaran.ru/author/ vygotskii_lev/vygotskill_lev_psihologiya_iskusstva/vygotskii_lev_psihologiya_iskusstva_I 7 .html> [accessed September I 3 2006].

${ }^{42}$ Compare Harold Jenkins's thoughts in this connexion, Jenkins (ed.), Hamlet, London, I989, pp. I36-40. On the uniqueness of Hamlet, see ibid., pp. I22-24.

43 Paraphrase by Anthony Savile, in his The Test of Time, Oxford, I982, p. I34. The German reads: 'Es scheint, als wenn er uns alle Rätsel offenbarte, ohne daß man doch sagen kann, hier oder da ist das Wort der Auflösung.' (Johann Wolfgang von Goethe, Wilhelm Meisters Lehrjahre, III. I I.)

${ }^{44}$ Hungarian ösztön may also be paraphrased as "impulse", "urge", "drive", even "desire". 
that, like a dog, could only howl and not speak, and it was the empty (üres) air that was held aloft in the pure (tiszta) twilight. The complexity and opacity of 'Szürkület' is also derived, in part, from the fact that the text is fragmentary, unfinished; and the overall stylistic effect - to put it vaguely — is reminiscent of one of Hamlet's soliloquies. ${ }^{45}$

In terms of its themes and rhetoric, however, 'Szürkület' shows striking similarities to two of Hamlet's soliloquies in particular: back-to-back soliloquies at the end of Act II and the start of Act III. The rhetorical device of enumeration occurs in both, but it is the specifics of theme that buttress the impression of likeness: failure of instinct, ambiguity of action/agency, and abuse, real or imagined. Alongside József's mute instinct we have Hamlet's 'native hue of resolution/ [...] sicklied o'er with the pale cast of thought' (III.I.84-85); compare also 'Yet I,/ a dull and muddy-mettled rascal, peak/ like John-a-dreams, unpregnant of my cause,/ and can say nothing' (II.2.56I-564), wherein Hamlet's 'dull revenge' (IV.4.33) is cast in metaphors of muteness and non-pregnancy, both thematically central to 'Szürkület'. ${ }^{46}$ The list of instances of ill-treatment in lines I8-20 and 23 of 'Szürkület' are closely paralleled by Shakespeare's enumeration 'Who calls me villain, breaks my pate across, / plucks off my beard and blows it in my face,/ tweaks me by the nose, gives me the lie i' th' throat/ as deep as to the lungs — who does me this?' (II.2.567-70): we have detailed verbal and physical abuse, all presented paratactically. More abstract, but also parallel is the enumeration in the lines 'Th' oppressor's wrong, the proud man's contumely,/ the pangs of dispriz'd love, the law's delay,/ the insolence of office, and the spurns/ that patient merit of th' unworthy takes' (III.I.7 I-74); the alternative, suicide ('quietus', 'bare bodkin' III.I.75-76) is paralleled by József's own suicide.

As far as style and rhetorics are concerned, what needs to be stressed is how Shakespearean paratactic pairings and hendiadys are, and specifically: how typical of Hamlet. Frank Kermode has treated this recently in some depth, ${ }^{47}$ but it is George T. Wright we have to thank for the trailblazing. ${ }^{4}$ Wright points out that hendiadys is a rarely-used tool in the English poetic workshop ${ }^{49}$ it is of rare occurrence in Hungarian, as well. ${ }^{50}$

45 Compare Thomas Kabdebo's astute observation, which he does not elaborate or explain, that all József's late poems are aubades 'which employ rhyme and Hungarian verse rhythms, with the sole exception of Dusk [Szürkület], which has an iambic beat not dissimilar to one of Hamlet's soliloquies'. Thomas Kabdebo, Attila József: Can you take on this awesome life?, Budapest, I997, p. I6I.

${ }^{6} 6$ József's use of éles 'sharp' together with tiszta 'pure' in the first line also plays a role here. These two adjectives form a commonplace pairing in Hungarian, but in the context of this poem their semantic continuum is particularly apt: "sharp — clear — clean - pure" is both appropriate to the filigree branches of lines $2-3$ and oxymoronic in connection with twilight. The central idea here is the disintegration of the person(ality).

47 Kermode, Shakespeare's Language, esp. p. Iooff.

${ }^{8}$ George T. Wright, 'Hendiadys and Hamlet', PMLA, 96, I98 I, 2, pp. I68-93.

49 Ibid., p. I69. It is nevertheless odd that Geoffrey Leech pronounced himself unable to find a single certain instance of hendiadys in English literature (A Linguistic Guide to English Poetry, London, I969, p. 4). Hendiadys is also scarcely treated in translation theory, though its connexion with language typology is unavoidable; see, however, Joseph L. Malone's The Science of Linguistics in the Art of Translation: Some Tools from Linguistics for the Analysis and Practice of Translation, Albany, NY, I988, pp. 2 I I-I2.

so An older etymology of Hungarian és 'and', now no longer in favour, derived it from the same material seen in the adjective-forming derivational suffix $=s$; thus the noun phrase él=es kés "sharp knife" would be identical, in terms of its ancestry, with the hendiadys of él és kés "edge and knife". If this scenario is correct, hendiadys in present-day Hungarian is rare and novel because it has been thoroughly lexicalized: 'it's so old, it's new'. See TESz, I, p. 793. 
For the textual and lexical specifics, I concentrate on metre and a few select words and phrases. In 'Szürkület', József uses mainly iambic tetrameter, but in such a way as to invoke not only the metre of dialogue in Ancient Greek tragedy, but also Shakespeare's iambic pentameter. This is partly because József's handling of the metre is a complex composite of Hungarian laza jambus ${ }^{5 \mathrm{I}}$ with purely tonic readings in the style of mainstream English tonosyllabic verse, but specifically resembling its relatively daring deployment by Shakespeare in his dramatic poetry..$^{52}$ Because of the dominant syllable count (twelvers) there is also tension with the 'noble' traditional Hungarian tizenkettes line. ${ }^{53}$ Shakespeare's iambic pentameter, especially in the later plays, is rife with enjambement and mid-line sentence-breaks, even aposiopesis. ${ }^{54}$ This is precisely what we have in 'Szürkület', with enjambement at lines I 2 and I6, and mid-line sentence breaks in seven lines (6, IO, I3, I7, 20, 27, and I8).

At the level of lexis, the phrase tar ágak, with which József sets the scene, is one that he had written down earlier and survives as part of a fragment. ${ }^{55}$ We may paraphrase: "bare boughs". The imagery is reminiscent of the imagery that opens Shakespeare's seventy-third sonnet, elaborating on the conventional metaphors 'death is darkness/night', 'a lifetime is a day/year', and some of the words used to implement these metaphors are bare and boughs, along with Shakespeare's only use of the word twilight, an 'equivalent' to szürkület.

Finally, the chiastic doubling of the synonyms makacs, ravasz, csökönyös and kétszinü has already been mentioned as notably Shakespearean because of their readings as hendiadys, but intertextually, they recall the Queen's characterization of Pisanio as a 'slye, and constant knaue' in Cymbeline (I.5.86). Seen through the lens of hendiadys, the positive and negative polarities of slyness and constancy are reversed: a faithful ('constant') servant often serves his

5I "loose iambics": a set of metres that developed in Hungarian from the mid-nineteenth century. Practice varies, but the most basic rule is that even-numbered syllables should be quantitatively long, stressed, or both. The metre is thus itself a composite of quantitative and tonic variables.

52 'Hamlet is still an early enough play that deviant numbers of syllables or feet do not appear with disquieting frequency, but even here most extended speeches include some departures from pattern.' George T. Wright, Shakespeare's Metrical Art, Berkeley, CA, I988 (hereafter Metrical Art), p. I02. See also Daniel Abondolo, 'Over-Egging Shakespeare: Varieties of Density in Hungarian Translation', in László Péter and Martyn Rady (eds), British-Hungarian Relations since 1848, London, 2004, pp. 329-43.

53 The tizenkettes is also known as the Hungarian alexandrine. It is instructive to consider here Gedeon Mészöly's (I 880-I960) plea concerning the best Hungarian metres for the translation of Homer. Mészöly, who himself translated Homer, reckons with cross-cultural equivalence in the realm of genre and form, something I am not prepared to do. I paraphrase: "Translation is faithful when it is not only beautiful, but when its beauty is of the same style as that of the beauty of the original, and a Hungarian translator will hit upon the correct verse-form when (s)he selects that Hungarian form which is equivalent, in Hungarian poetic practice, to the dactylic hexameter of Ancient Greek", 'Az Odisszea magyarra fordításának módszere', in Népünk és nyelvünk. Válogatott tanulmányok, Budapest, I982, pp. 550-74 (550); appeared originally in unabridged form as 'Az Odüsszeia magyarra fordításának módszere', Acta Universitatis Szegediensis, Nyelv és Irodalom series II (1956), pp. 6-49.

${ }^{54}$ Compare Metrical Art, esp. pp. 209-Io.

ss Compare Stoll, JAÖV, II.428. It was also a favourite phrase of the poet Gyula Juhász (I883-I937), early mentor and friend to József, whose suicide preceded József's by eight months. Stoll has recently claimed to have discovered József's last poem in a work previously thought to have been merely a draft of his elegy on Juhász's death. If, as seems likely, Stoll is correct, by deleting the sextet and altering two words in the remainder of this sonnet, József converted this elegy on Juhász's death into his own suicide note. See Stoll's 'József Attila utolsó verse', in Irodalomismeret Online, 2000, no. 4 <http:// irodalom.web.elte.hu/iris/arch/cikkek/ 2000_4/jastollb.html> [accessed February I4 2006]. 
master best by being skilful ('slye') in disobeying him. And the persona of 'Szürkület', by characterizing himself as cunning and stubborn, suggests that he has the skills of both fox and hedgehog.

If, as his reputation in Hungary suggests, Attila József achieved greatness, it was a greatness akin to Shakespeare's in the sense that both men produced poetry of unusually high formal and contentual complexity. Both were exceptionally skilled in the manipulation of language. Shakespeare was doubtless the healthier man, but both men had minds that I should call, in the context of this essay, teeming. To paraphrase Antal Szerb:

There are modern poets whose work achieves greatness because they envelop, in a halo of beauty, the treasures of our culture, our thoughts, our history, our art; such was Mihály Babits. And there are modern poets whose magic consists in the fact that their words and images transcend the understanding, they catch us unexpectedly and give us a shake, and make us receptive to a presentiment of the Great Secret; such was Attila József. ${ }^{56}$

But it is not only 'modern' poets whose 'word magic' can transcend understanding. In József's 'Szürkület' we have a reworking, in miniature and by means of covert 'translation', of Shakespearean style, lexis, and theme..$^{57}$

\section{APPENDIX}

The Hungarian text, as reconstructed by Stoll (see note 20), is given in the left column, with one alteration: I write a-macron $(\bar{a})$ to indicate metrically long readings of the definite article. In the right column is an English text consisting of glosses patched together to form something approaching readable prose. Superscript numerals are intended to assist the reader with little or no Hungarian to match up the latter with the former.

Ez éles, tiszta szürkület való nekem.

A távolban ${ }^{\mathrm{I}}$ tar ${ }^{2}$ ágak ${ }^{3}$ szerkezetei

tartják keccsel az üres levegőt.

A tárgy-egyén mind elválik a többitől,

5 magába mélyed és talán megsemmisül.

Ki tudja ? Válaszolna erre ösztönöm, de mint az eb, melyet gazdája megszidott s kedvetlenül borong a rideg udvaron $\mathrm{s}$ ha idegen jö, rávonít, de nem beszél,

IO olyan most ő. Mihez foghatnék nélküle ? Csak egy bizonyos itt — az, àmi tévedés. Még jó, hogy vannak jambusok és van mibe

beléfogóznom. - Járni gyermek így tanul. Hisz gyermek is csupán azért nem lehetek,

I5 mert 'túlnyügös ²volnék, makacs és kétszinú, talán mivelhogy minden ember épp ilyen ravasz és csökönyös, ha az — hogy tudjam én?
This sharp pure twilight is true/right for me. In the distance the ${ }^{3}$ mechanisms of ${ }^{\mathrm{I}}$ bare ${ }^{2}$ boughs hold with grace the empty air.

The object-individual all separates from the rest into itself it sinks and perhaps is annihilated. Who knows? It would answer, my drive, but like a dog, which its master has scolded and (which) dejectedly broods in the bleak yard and if a stranger comes, he howls at him, but does not speak, such now is (s)he. What could I do without it? Just one (thing) is certain here - that which is error. It's a good thing that there are iambs and there is something for me to hold on to. - To walk a child thus learns. For - I cannot be even a child if only for the reason that ${ }^{2}$ I would be ${ }^{\mathrm{I}}$ too tetchy, stubborn and two-faced, perhaps since every person to just that degree is cunning and obstinate, if he is those things - how should I know?

56 A világirodalom története ("History of World Literature”), Budapest, I94I, p. 243.

57 I dedicate this essay to the memory of my teacher Robert Austerlitz (I923-94), who introduced me to József's work thirty-five years ago. 
Az egyik rámkacsint s azt mondja, szép fiú s a másik : randa dög, megint nem dolgozol, de hasadat azt félted! (Hát ne féltsem-e ?) one winks at me and says, nice boy and the other: ugly carrion, again you do not work, but your belly, that you fear for! (why, should I not fear for it?)

Ez pénzt nyom ā kezembe s így szól : Boldogulj, This one presses money into my hand and speaks thus: godspeed,

megértelek, szenvedtem én is eleget $s$ amaz ellopja tőlem a szemetet is. Ez ideránt, az odahúz, mind fogdos, vartyog, taszigál,

25 de 'észre ${ }^{2}$ egyikük sem ${ }^{\mathrm{I}}$ veszi púpomat, mit úgy hordok, mint őrült anya magzatát, amellyel némaságot szûl — azt hiszi ő - .

vagy ősi, tiszta ûrt. Viselem púpomat ődöngve én a hemzsegő körútakon 30 és senki
I understand you, I, too, have suffered enough and that one steals from me even my trash. This one yanks me this way, that one pulls me that way, all grope me, croak, poke-and-push me, but ${ }^{2}$ not one of them ${ }^{\mathrm{I}}$ notices my hump, which I carry, as a mad mother her embryo, by which she will give birth to silence - so she believes

or ancestral, pure emptiness. I bear/wear my hump sauntering I on the swarming boulevards and no one 